\title{
Cytological Studies on Some Egyptian species of Anthemideae (Asteraceae)
}

\author{
A.M. Ata, M.H. Abd El-Twab*, R.K. Helmey** and H. Dahy* \\ Genetics Department, Faculty of Agriculture and *Botany \& Microbiology \\ Department, Faculty of Science, Minia University, Minia, Egypt.
}

\begin{abstract}
HE MEIOTIC behavior and morphology of pollen grains of four species of Asteraceae (Glebionis coronaria, Anacyclus monanthos, Matricaria recutita and cotula barbata) were studied. Glebionis coronaria, Anacyclus monanthos and Matricaria recutita showed nine chromosome bivalents while those of Cotula barbata showed eight chromosome bivalents. The chromosomes were meiotically identified as two pairs in three taxa (Glebionis coronaria, Anacyclus monanthos and Matricaria recutita) while it was one pair in Cotulabarbata. The pollen shape and morphology were recognized by measuring polar and equatorial axis, Morphological characteristics of the pollen grains of the four studied species were considerably different.
\end{abstract}

Keywords: Cytological studies, Egyptian species of Anthemideae, Meiotic, Pollen morphology.

\section{Introduction}

Chromosome numbers and karyotype analysis of somatic chromosomes have been described for several species of Asteraceae in Egypt. Detailed karyotype features of 23 species of subfamily Asteroideae were described by Badr et al. (1997) and for 24 species from the tribes Chicorieae (Lactuceae) and Cardueae (Cynareae) by Badr et al. (2009). Comparative karyological analysis was also described for selected species such as Artemisia judaica and Artemisia monosperma (Badr et al., 2012). Additional counts were added on Cotula barbata, Achillea fragrantissima, Achillea santolina, Anacyclus monanthos, Artemisia arborescens, Glebionis coronaria, Cotula cinerea and Matricaria recutita (Abd El Tawab et al., 2008; 2012 and Badr et al., 2014). Diploid and polyploid somatic chromosome numbers based on $x=5,7.8,9$ and 11 have been reported and karyotype symmetry indicators i.e. the values of the mean arm ratio, $\mathrm{TF} \%, \mathrm{~A}_{1}$ and $\mathrm{A}_{2}$ indices, clearly demonstrated that the karyotype is generally symmetric with small variations between the chromosomes in length and centromere position (Badr et al., 1997 and 2009). However, none of the above-mentioned studies have addressed meiotic chromosomes.

According to the observations of numerous authors, palynological studies provide an excellent set of characters that complement traditional morphological studies, and contribute to the understanding of the taxonomy, phylogeny and ecology of the Asteraceae. The complexity of the Asteraceae pollen often includes the characteristics of the aperture system, an issue widely discussed by several authors because of the different techniques of observation used and the heterogeneity of this taxonomic group (Montes \& Murray, 2105).

The main goal of this work is to investigate the behavior of meiotic chromosomes and pollen grain morphology of four species of Asteracaea collected from different localities of Egypt.

\section{Materials and Methods}

\section{Plant material}

Plants of four species from the tribe Anthemideae, family Asteraceae were collected at flowering and fruiting stages from plants growing in their natural habitats and identified using the manual Students Flora of Egypt (Täckholm, 1974). Plant species used in this cytological study are Glebionis cronaria (L.), Matricaria recutita (L.), Anacyclus monanthos (L.) Thell., and Cotula barbata DC.(Table 1 and Fig. 1).

"Corssponding auther email: rashahelmey@yahoo.com DOI: $10.21608 /$ ejbo.2017.837.1058

C2017 National Information and Documentation Centre (NIDOC) 
TABLE 1. Plants from different taxa at tribe Anthemideae from family Asteraceae and their localities in Egypt

\begin{tabular}{ll}
\hline Species & Location \\
\hline Glebionis coronaria & Minia University and Cairo-Alexandria desert Road \\
Matricaria recutita & Minia University \\
Anacyclus monanthos & Borg El-Arab \\
Cotula barbata & Minia University-Botanical garden of Agriculture faculty \\
\hline
\end{tabular}

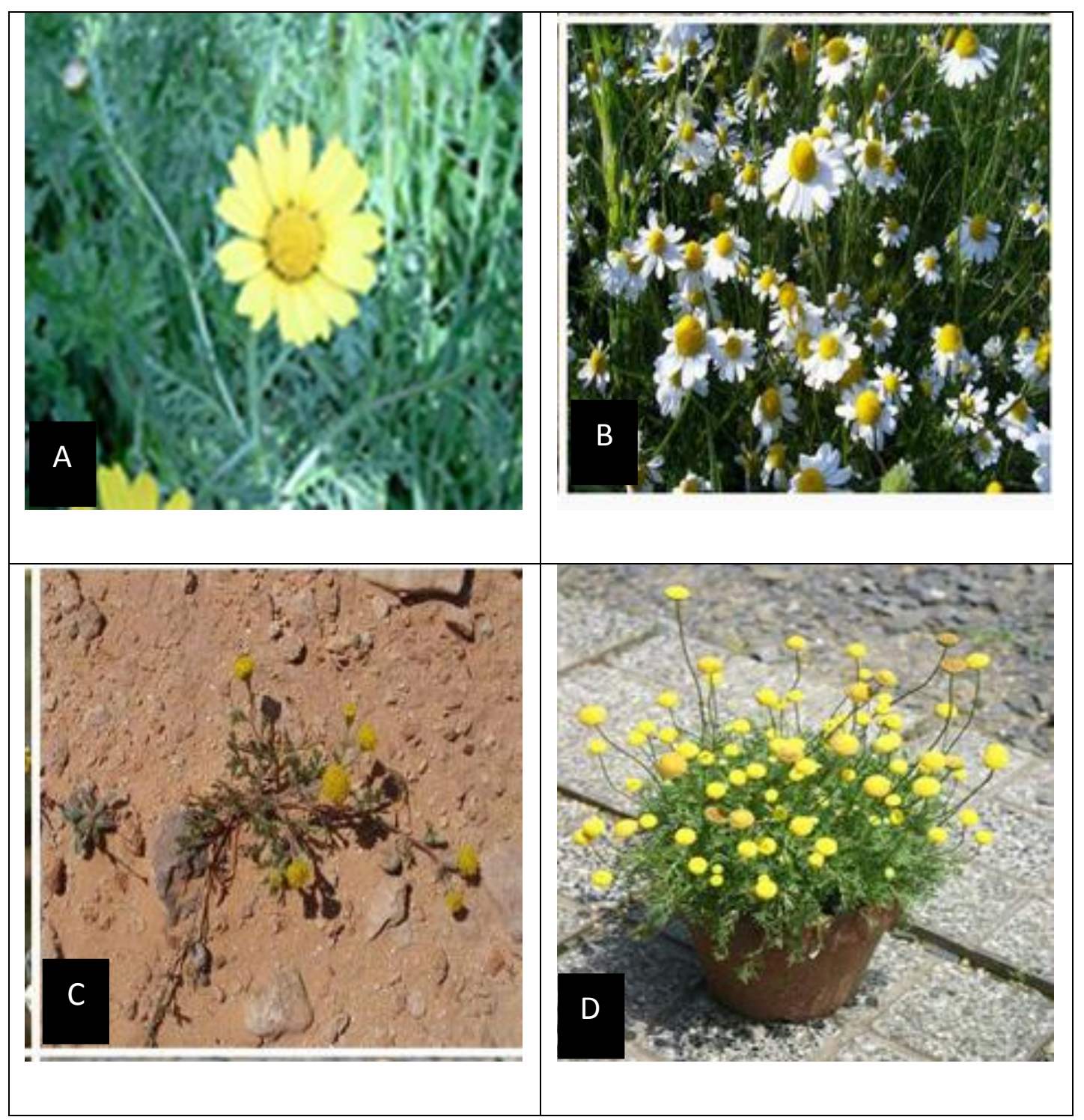

Fig. 1. Photographs of plants of the studied taxa. A. Glebionis coronaria, B. Matricaria recutita, C. Anacyclus monanthos and D. Cotula barbata. Bar equals 4 microns. 


\section{Meiotic preparation}

Young flowering buds (45 days aged plants) were collected and immediately fixed (3 ethyl alcohol: 1 acetic acid) for $24 \mathrm{~h}$ at $4^{\circ} \mathrm{C}$. The meiotic behavior of chromosomes in pollen mother cells (chromosome pairing) was examined in at least (50 cells / species). Aceto-carmine stained microscopic slides were prepared from mature anthers and viable pollen grains (with the stained protoplast) were counted. The number of bivalents, the ring and rod units, and chiasma frequency per cell and per bivalents were recorded. Some PMCs were photographed using Olympus C-4040 Camera. Pollen grain morphology was also examined in large flowering buds and photographed. Measurements of pollen grains were taken using SIS image analysis. Chiasma frequency per bivalent, ring frequency, rod frequency and LSD were calculated using MSTAT program.

\section{Results and Discussion}

Pollen mother cells (PMCs) of plants of species G. coronaria, A. monanthos and M. recutita showed nine bivalents while those of species $C$. barbata showed eight bivalents at diakinesis and metaphase I (Fig.2). According to chiasma number, position and pairing pattern, the chromosome bivalents were classified either ring (there are two chiasmata or more located along with chromosome or rod (pairing between the two homologous chromosomes is at one chromosome end and only one terminal chiasma is observed). PMCs of species of G. coronaria showed nine bivalents at diakinesis (Fig.2A). Mean number of rod and ring bivalents at diakinesis in species of G. coronaria were 2.795 and 6.205 , respectively. The chiasma frequency per cell and per bivalent were 15.26 and 1.695 , respectively as shown in Table 2. PMCs of species M. recutita showed nine bivalents at diakinesis (Fig. 2B).Mean number of rod and ring bivalents in species $M$. recutita were 3.3 and 5.7, respectively. The chiasma frequency per cell and per bivalent were 14.69 and 1.63 respectively (Table 2). Similarly, PMCs of plants of species A. monanthos showed nine bivalents and the nucleolus is associated with two bivalents at diakinesis (Fig. 2C). Mean number of rod and ring bivalents in A. monanthos were 3.231 and 5.769, respectively. The chiasma frequency per cell and per bivalent were 14.77 and 1.641, respectively (Table 2). PMCs of plants of species C. barbata showed eight bivalents at diakinesis (Fig. 2D). The nucleolus was seen associated with one bivalent. Mean number of rod and ring bivalents in species C. barbata were 7.231 and 0.7692 , respectivelly and the chiasma frequency per cell and per bivalent were 10.85 and 1.356 , respectively (Table 2).

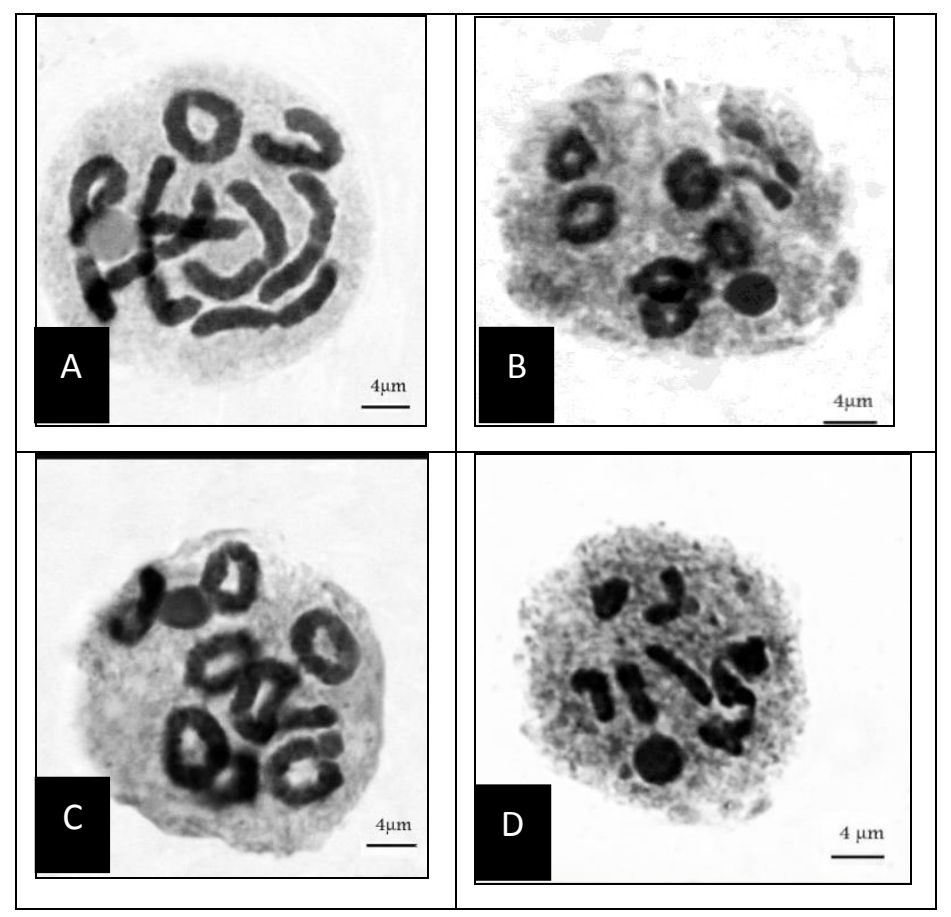

Fig. 2. Stages of meiosis (Diakinesis) showing ring and rod bivalents. A. Glebionis coronaria., B. Matricaria recutita, C. Anacyclus monanthos and D. Cotula barbata. Bar equals 4 microns. 
TABLE 2. Mean number of ring and rod bivalents and chiasma frequencies of the four species of Asteraceae.

\begin{tabular}{lccccc}
\hline Species & $\begin{array}{c}\text { Number of } \\
\text { counted cells }\end{array}$ & $\begin{array}{c}\text { Chiasma } \\
\text { frequency per } \\
\text { cell }\end{array}$ & $\begin{array}{c}\text { Chiasma } \\
\text { frequency per } \\
\text { bivalent }\end{array}$ & Ring & Rod \\
\hline $\begin{array}{l}\text { Glebionis } \\
\text { coronaria }\end{array}$ & 50 & 15.26 & 1.695 & 6.205 & 2.795 \\
$\begin{array}{l}\text { Matricaria } \\
\text { recutita }\end{array}$ & 50 & 14.69 & 1.632 & 5.692 & 3.308 \\
$\begin{array}{l}\text { Anacyclus } \\
\text { monanthos }\end{array}$ & 50 & 14.77 & 1.641 & 5.769 & 3.231 \\
$\begin{array}{l}\text { Cotula barbata } \\
\text { LSD 0.05 }\end{array}$ & 50 & 10.85 & 1.356 & 0.7692 & 7.231 \\
\hline
\end{tabular}

The pollen grains of four representative species belonging to Asteraceae were shown in Fig.3. The pollen shape and morphology were recognized by measuring polar and equatorial axis (Table 3). All pollen grains of Glebionis are oblate-spheroidal and the pollen walls are provided with spines (Fig. 3A.). The polar axes 22.23-29.95 $\mu \mathrm{m}$ and the equatorial axes $24.65-31.79 \mu \mathrm{m}$. The pollen grains of $M$. recutita are operculate and tricolporate and the pollen wall is provided with spines with the polar axes $15.12-20.88 \mu \mathrm{m}$ and the equatorial axes 16.18- $22.76 \mu \mathrm{m}$ (Fig. 3B). All pollen grains of Anacyclus are oblate-spheroidal with the polar axes 11.8- $14.88 \mu \mathrm{m}$ and the equatorial axes 12.5$15.31 \mu \mathrm{m}$. The pollen wall is smooth (Fig. 3C). All pollen grains of $C$. babata are sub-oblate with the polar axes 15.9- $23.03 \mu \mathrm{m}$ and the equatorial axes 18.53- $25.4 \mu \mathrm{m}$, they are operculate and tricolporate and the pollen wall is provided with spines (Fig. 3D).

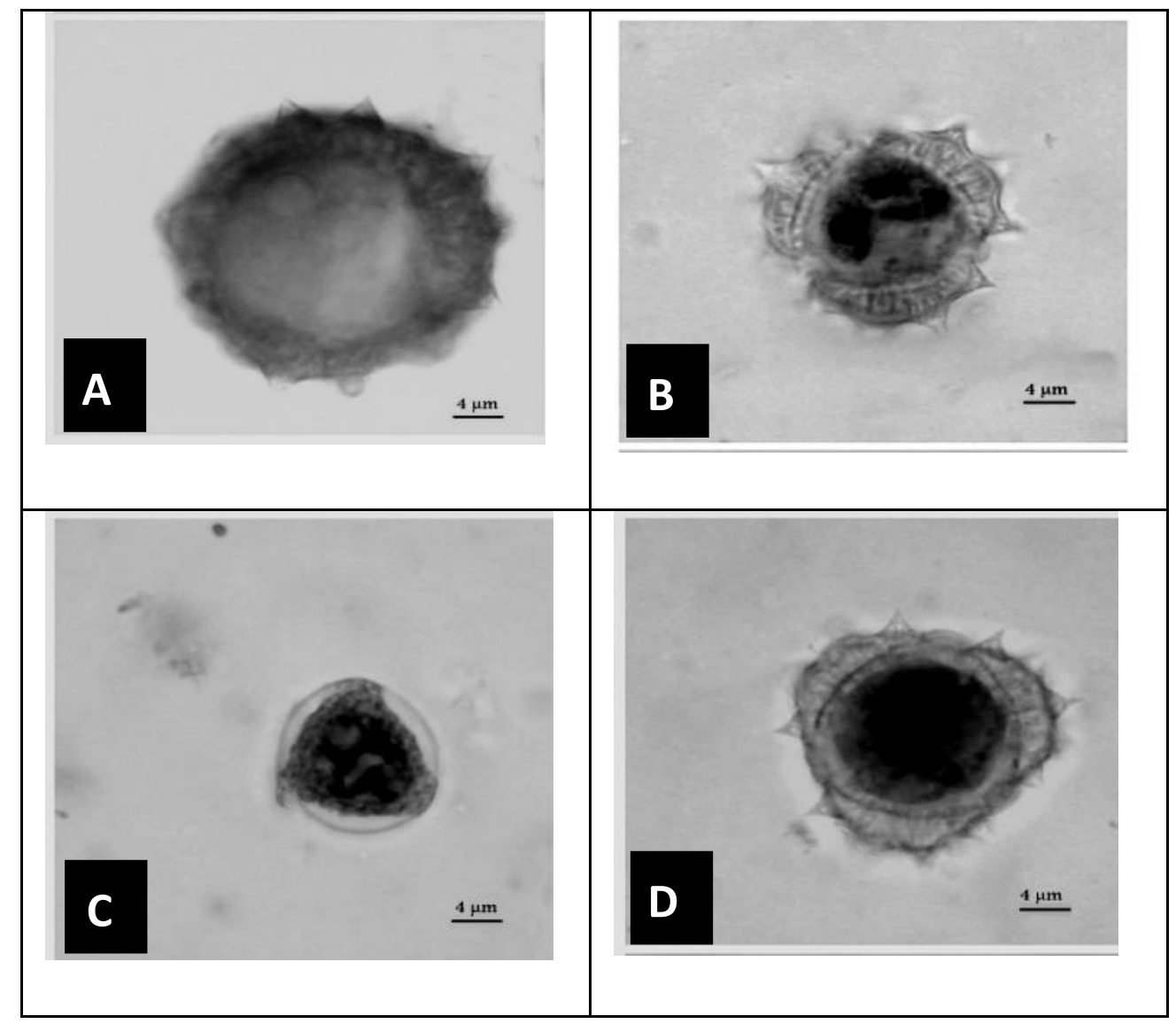

Fig. 3. Pollen microphotography of A. Glebionis coronaria., B. Matricaria recutita, C. Anacyclus monanthos and D. Cotula barbata. Bar equals 4 microns. 
Morphological characteristics of the pollen grains of the four studied species were considerably different. These data are in accordance with those reported by Bose et al.(2012). These differences are used to differentiate between genera and even species. For example, in Matercaria species, seven major pollen types have been recognized on the basis of type and number of aperture shape, aperture type and ornamentation (Ceter et al., 2013).

Cytological data presented herein are in agreement with several works (Abd El-Twab et al, 2008; Humphries, 1980; Powell et al, 1974 and Schweizer \& Ehrendorfer, 1976). The observed regular meiosis suggested that intra- and inter-genomic reorganization process occur quickly and efficiently in these taxa. The higher number of the ring bivalents at diakinesis and metaphase I may be attributed to median centomeric positions on the chromosomes of these taxa (López et al., 2013). As a rule, metacentric and submetacentric chromosomes formed ring bivalents, while acrocentrics and subtelocentrics paired in rod units during first meiotic prophase and metaphase I. The karyotype structures, composition and distribution of the heterochromatin in Glebionis coronaria and Glebionis segetum using Giemsa and fluorescent banding techniques were also analyzed by Paciolla et al. (2010). They concluded that G. coronaria possesses the most symmetrical karyotype, comprising mainly metacentric chromosomes. The formation of rod bivalents in spite of rings in the existence of metacentric and submetcentric chromosomes observed at diakinesis and metaphase I in the present materials may due to different pairing conditions, degree of homology and recombination systems.

Chiasma frequency per chromosome depends on the length and homology of chromatin content. The data revealed that the lowest value of chiasma frequency per chromosomes was in plants of $C$. barbata. This is not due to low haploid number $(n=8)$ but to chromosome length. The frequency of chiasma differences were extensively analyzed in several taxa belonging to Asteraceae (Ghaffari \& Djavadp, 1998; Gupta et al., 2013; Kumari \& Sidhu, 2012 and Sheidai et al, 2006). They concluded that the cytotaxonimic features verify the affinity of the related taxa of Asteraceae. The principal taxonomic problems within the tribe Anthemideae are almost entirely relationships between genera, but also circumscription of 
genera, especially within subtribal groups such as the Artemiisinae, Chrysantheminae and Tanacetinae (Bremer \& Humphries, 1993). Although the Anthemideae tribe has been reviewed extensively (Bremer \& Humphries, 1993), small karyotype changes appear already within species and gradually reduce chromosome pairing affinities in species hybrids. Gross translocations and loss of centromeres have led to species divergence and descending dis-ploidy $(2 \mathrm{n}=16 \sim \mathrm{t} 2)$. Some species of Anacyclus were karyologically examined by Humphries (1980) and indicated that evolution in genus Anacyclus has been accompanied by chromosomal re-patterning. The understanding of the relationships of the annual of these taxa is complicated by sympatry and the occurrence of natural hybrids.

Chromosomes with nucleolar organizer were meiotically identified as two pairs in the three taxa $G$. coronaria, $A$. monanthos and $M$. recutita while it was one pair in C. barbata. Chromosome numbers, morphology and nucleolus organizer region (NOR) locations are useful cytological characters for taxonomic and evolutionary studies (Barth et al., 2013). Recently, molecular cytogenetic localization of rDNA genes was achieved in different species belonging to Asteraceae (Bernardes et al., 2013 and Abd El-Twab et al., 2015). Thus, the presence of repetitive DNA clusters (rDNA sites and fluorochrome bands) suggested the great importance of such DNA elements during the karyotype evolution. The karyological markers developed allowed karyotypic differentiation between both species, uncovering peculiarities in the number and position of rDNA sites, which suggests chromosome rearrangements, such as translocations (Bernardes et al., 2013). Genetic variation within and between plant populations is essential for establishment the genetic diversity database of plant genetic resources (Badr et al., 2012; 2014 and 2016).

\section{Conclusion}

Cytological configuration at first meiotic division and pollen morphology were described in four species of Asteraceae (Glebionis coronaria, Anacyclus monanthos, Matricaria recutita and cotula barbata). The number, type, position and distribution of chismata in the bivalent were described. In addition the shape and characteristics of pollen in the examined species are described in detail.

\section{References}

Abd El-Tawab, M H., Mekawy, A.M. and El-Katatny, M.S. (2008) Karyomorpho-logical studies of some species of Chrysanthemum sensulato in Egypt. Chromosome Botany, 3, 41- 47.

Abd El-Twab, M.H., Mekawy, A.M. and El-Katatny, M.S. (2012) Karyomorphology of six taxa in Chrysanthemum sensulato (Anthemideae) in Egypt and their genetical relationships by Giemsa C-banding. Journal of Systematic and Evolution, $\mathbf{5 0}$ (1), 58-63.

Abd El-Tawab, M.H., Dahy, H., Helmey, R.K. and Atta, A.M. (2015) Characterization of chromosome complement in Achillea fragrantissima (Forssk) Schultz-Bip. Analyzed by DAPI and FISH. Chromosome Botany, 10, 7-11.

Badr, A., Kamel, E.A. and Garcia-Jacas, N. (1997) Chromosomal studies in the Egyptian flora. VI. Karyotype features of species in subfamily Asteroideae (Asteraceae). Compositae Newsletter, 30, 15-28.

Badr, Hanaa A.H. El-Shazly and Kamel, E.A. (2009) Chromosomal studies in the Egyptian flora. VII. Karyotype analysis of species in the two tribes Chicorieae and Cardueae of Asteraceae. Egypt. J. Bot. 49, 71-86.

Badr, Hanaa A.H. El-Shazly, Nagah, S.H. and El Ghanim, Wafaa (2012) Genetic diversity of Artemisia populations in central and north Saudi Arabia based on morphological variation and RAPD polymorphism. Plant Syst. Evol. 298- 871.

Badr, A., Sayed Ahmed, H.I., Hamouda, M. and El-Khateeb, E.A. (2014) Genetic diversity in Egyptian populations of Achillea santolina using morphological traits and ISSR markers. Taeckholmia, 34, 49-65.

Badr, Hanaa A. H. El-Shazly, Sayed Ahmed, H.I., Hamouda, M., El-Khateeb, E.A. and Sakr, M. (2016) Genetic diversity of Achillea fragrantissima in Egypt inferred from phenotypic variations and ISSR markers associated with traits of plant size and seed yield. "Plant Genetic Resources: Characterization and Utilization". pp.1-9.

Barth, A., Souza, V.A., Sole, M. and Costa, M.A. (2013) Molecular cytogenetics of nucleolar organizer regions in Phyllomedusa and Phamahyla species (Hylidae, Phyllomedusinae): a cytotaxonomic contribution. Genetic and Molecular Research, 12, 2400-2408.

Bernardes, E., Benko-Iseppon, A.M.,Vasconcelos, S., Carvalho, R. and Brasileiro-Vidal, A.C. (2013) Intra-and interspecific chromosome polymorphisms 
in cultivated Cichorium L. species (Asteraceae). Genetics and Molecular Biology, 36 (3), 357-363.

Bose, A., Roy, B. and Paria, N.D. (2012) Study of pollen morphology of some dicotyledonous plants occurring in Ballygunge Science College Campus. J. Botan. Soc. Bengal. 66 (2), 111-117.

Bremer, K. and Humphries, C.J. (1993) The generic monograph of Asteraceae-Anthemideae. Bull. Nut. Hist. Mus. London (Bot.), 23, 71-177.

Ceter, T., Nur, M., Pinar, H., Inceer, S., Hayirliog, luAyaz and Yaprak, A.E. (2013) The comparative pollen morphology of genera Matricaria L. and Tripleurospemum Sch. Bip.(Asteraceae) in Turkey. Plant Syst.Evol. 299, 959-977.

Ghaffari, S.M. and Djavadp, S.B. (1998) Chromosome studies and distribution of nine species of Cousinia section stenocephalae (asteraceae) in Iran. Bulletin de la Sociéténeuchàteloise des Sciences Naturelles, 121, 61-68.

Gupta, R.C.,Bala, S., Sharma, S. and Kapoor, M. (2013) Cytomorphological studies in some species of Chrysanthemum L. (Asteraceae). Chromosome Botany, 8, 69-74.

Humphries, C.J. (1980) Cytogenetic and cladistic studies in Anacyclus (Compositae: Anthemideae). Nord. J. Bot. 1, 83-96.

Kumari, S. and Sidhu, M.C. (2012) Meiotic studies in Cosmos sulphurous Cav. Chromosome Botany, 7, 117-118.
López, M.G., Xifreda, C.C., Poggio, L. and Wulff, A.F. (2013) Deep cytogenetics analysis reveals meiotic recombination depletion in species of Senecio (Asteraceae). Botanical Studies, 54, 20.

Montes, B. and Murray, M.G. (2015) Pollen morphology of Seneciobergii (Asteraceae), with special attention to the meso-aperture. FYTON, 84, 201-208.

Paciolla, C., Demerico, S., Tommasi, S. and Scrugli, A. (2010) Karyomorphological and biochemical studies in Glebionis coronaria (L.) Spach and Glebionis segetum (L.) Fourreau from Italy, Plant Biosystems- An International Journal Dealing with all Aspects of Plant Biology: Official Journal of the Societa Botanica Italiana, 144(3), 563-567.

Powell, M., Donald, A., Kyhos, W. and Raven, P.H. (1974) Chromosome numbers in compositae. American Journal of Botany, 61(8), 909-913.

Schweizer, D. and Ehrendorfer, F.W. (1976) Giemsa banded karyotypes, systematics, and evolution in Anacyclus (Asteraceae- Anthemideae). Plant Systematics and Evolution, 126, 107-148.

Sheidai, M., Mehdigholi, K.,Ghahreman, A. and Attar, F. (2006) Cytogenetic study of the genus Cousinia (Asteraceae, section Serratuloideae) in Iran Genetics and Molecular Biology, 29 (1), 117-121.

Täckholm, V., (1974) "Students Flora of Egypt" .Cairo University.(ed. 2), pp.888. 


\section{دراسات خلوية على بعض الأنواع المصرية من نباتات العائلة المركبة}

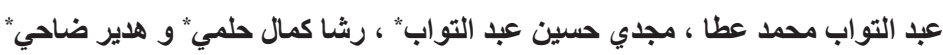

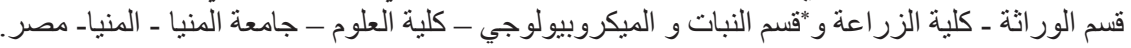

تم دراسة كل من سلوك الكروموسومات أثناء الانقسام الميوزي و الثكل الظاهري لحبوب اللقاح وذللك في أربعة انواع من

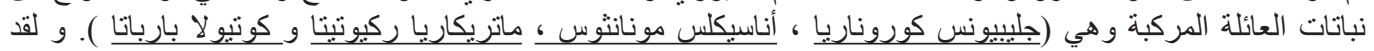

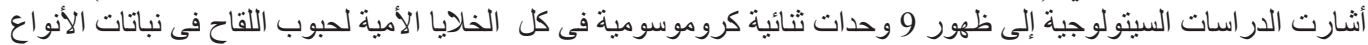

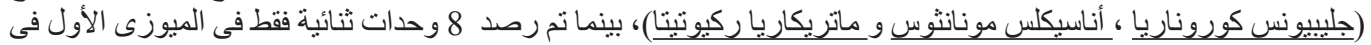
نباتات كو تيو لا بارباتنا.

ولقد أظهرت حبوب اللقاح تباين فى كثافة الكروماتين و الثكل الخارجى فى النباتات تحت الدر اسة وذلك عند تعيين قياسات لكل من المحور القطبى و الاستو ائى لحبوب اللقائ فئح. 